\title{
Sociolinguistic Study of Pet Names among Couples in Nsukka Metropolis, Nigeria
}

\author{
Chinedu Chidiebere Ezebube \\ Department of Linguistics, Igbo \& Other Nigerian Languages, University of Nigeria, Nsukka, Nigeria \\ Ogechukwu Uchenna Chukwuneke \\ Department of Linguistics, Igbo \& Other Nigerian Languages, University of Nigeria, Nsukka, Nigeria \\ Ekpereamaka Jennifer Onuagha \\ Department of Linguistics, Igbo \& Other Nigerian Languages, University of Nigeria, Nsukka, Nigeria
}

\begin{abstract}
This paper conducts a sociolinguistic study of pet names used among couples in Nsukka metropolis. It seeks to identify the pet names used among couples within Nsukka metropolis, examine the implications of the identified pet names, identify the sociolinguistic factors that contribute to the differences in the use of pet names among couples, and ascertain the language used by couples within Nsukka metropolis in communicating pet names. This research studies pet names used in six selected areas in Nsukka metropolis Echara, Ngwuru, Ihe n'Owerre, Amaeze, Nru, and University community. This study adopts the descriptive method in analysing the data gathered. From the findings, it is observed that couples within Nsukka metropolis use both English and Igbo pet names in addressing their spouses. The identified pet names are used by the couples in communicating what they feel for each other; either to express the masculinity or femininity of their partners or to express how beautiful or handsome their partners are, and to portray their respect for their partners. Sociolinguistic factors such as age, gender, occupation, region and educational background are identified to serve as determinants as to why couples use pet names. In conclusion, couples within Nsukka metropolis use pet names they feel are suitable in communicating their feelings for their spouses and also use the language they feel is appropriate in communicating the said feelings.
\end{abstract}

Index Terms—sociolinguistics, pet names, terms of address, Nsukka

\section{INTRODUCTION}

To everything that exists in the universe, there is a unique identity. Names can identify a class, category of things or a single thing either uniquely or within a given context. It can also mean a word or combination of words by which a person is designated or called. This implies that a person, thing, body or class is known by the name it bears. Invariably, a name refers to a word or term used for identification. It serves as a renewable label for a thing, person, product (brand name), even an idea or concept normally used to distinguish one from another (Olieh, 2001). The names of individuals are meaningful and they are as important as the persons that bear them. Humans are given names at birth that reflect something of significance or describe the course of their lives. The importance of a name cannot be over emphasised. In view of this fact, Bing (1993) opines that "besides having psychological roles in establishing a person's identity, names convey to those who know their origins and meanings, the social and cultural experiences of the people who created them" (p. 1). Names can be personal names, assumed names, Christian names, designated names (titles), family names, nicknames (sobriquets), pet names (affectionate names or terms of endearment) etc.

Naming is a universal cultural practice in the sense that every society has the habit of placing names on persons, objects and entities for distinction. The concept of naming is the process of assigning a word or phrase to a particular object, entity or property. This can be quite deliberate or a natural process that occurs in the flow of life as some phenomena come to the attention of the users of the language. Onomastics, which means the study of names has other branches which include; Anthroponomastics- the study of anthroponyms (proper names for a person or a group of people), Charactonym- study of names given to fictional characters in a piece of literature, Cryptonym- study of secret name which is used for the protection of the name bearer, Pseudonym- study of alternative names given to or used by a person in addition to or instead of an official or legal name, and Hypocorism- the study of pet names. For the purpose of this study, emphasis will be on hypocorism - the study of pet names or terms of endearment.

Pet names are names used by those who love or have affection for one another. It can also be seen as an affectionate substitute for a proper name. Therefore, it is a name that is used instead of someone's usual first name to express fondness or familiarity. Such names show how a friend sees the other or what they think of each other. These names also exist among couples; they are used to signify the importance of one to another. Nsukka is a town and a Local Government Area in the South Eastern Nigeria of Enugu state. Towns that share common borders with Nsukka are Eha Alumona, Edem, Alor-uno, Opi, Orba, Ede-Oballa, Obukpa and Obimo. Other nearby towns are Enugu Ezike, Obollo- 
Afor, Nimbo, Adani, Uzo Uwani and Mkpologwu. Nsukka town is the site of the University of Nigeria; which is also inhabited by the educated and the non-educated, the young and the old, the single and the married.

Pet names are remarkably universal methods of being demonstrative, showing affection and projecting tenderness. For instance, when a husband calls his wife "my treasure", he feels the wife is a rare gem and a gift to him. When this happens and the wife feels the husband addressed her rightly, it increases the level of attraction she feels for the husband. Some other names like mummy, obidiya, ugo $m$, asampete $m$, oyiridiya, angel, mine, darling, baby (for women) and daddy, nke $m$, di $m$ oma, odịkonamba, obiajụlu $m$, onyemjiribiri, oga $m$, nwokeoma (for men) give couples a sense of attachment to each other. Afful and Nartey (2013) further observe that terms of endearment refer "to words or expressions used in an interactive, dyadic and face-to-face situation by a speaker to address or describe a person for which the speaker feels love or affection for" (p. 92). The use of these names differs among couples due to social, emotional, psychological and marital factors. Therefore, the aim of this research work is to conduct a sociolinguistic study of pet names among couples in Nsukka metropolis, Nigeria. Specifically, the objectives are to:

i identify pet names used among couples in Nsukka metropolis;

ii examine the implications of pet names used among couples in Nsukka metropolis;

iii identify the sociolinguistic factors that contribute to differences in the use of pet names among couples in Nsukka metropolis; and

iv ascertain the language of communicating pet names among couples in Nsukka metropolis.

\section{REVIEW OF RELATED LITERATURE}

Sociolinguistics is a branch of linguistics that studies language in relation to the society. Hudson (1996) defines sociolinguistics as "the study of language in relation to society" (p. 4). Thus, in sociolinguistics, one studies language and society in order to find out as much as one can, what language is all about. However, Holmes (1992) says that "the sociolinguist's aim is to move towards a theory which provides a motivated account of the way language is used in a community and choices people make when they use language" (p. 16). For example, when one observes how varied language use is, one must search for the causes. These causes are known as their social correlates. In her own opinion, Mallinson (2015) believes that sociolinguistics aims "to study the effects of language use within and upon societies and the reciprocal effects of social organisations and social contexts on language use" (p. 13). Sociolinguists view language and society as being mutually constitutive; each influences the other in ways that are inseparable and complex.

Language is used in addressing people as well as communicating emotions. Addressing sometimes takes an emotional tone; addressees are called with friendlier, more passionate and more amiable tones. This marks the intimacy between the addresser and the addressee. Yule (2006) posits that words or phrases for a person being talked to or addressed are known as terms of address. More so, they are linguistic forms people in a conversation use in addressing themselves. It indicates certain relationships between people and also shows the difference in identity, position and social status. Mahzad (2012) further notes that terms of address are linguistic forms that are used in addressing others or to attract their attention or for referring to them in the course of conversation. These address terms are socially driven; they mirror the complex social relations of individuals in a speech community. Terms of address are also used in different contexts. For instance, terms of address used by couples may be different from those used by peers. Forms of address are correlated with the social status and interpersonal relationship between the addressee and the addresser. It is worthy to note that the address forms used to address someone depend on the relationship of the participants, their attitude to each other and the situation in which the conversation is happening. Thus, Holmes (1992) says that "the variation depends on the participants, setting, topic and function of the talk" (p. 12). It is also affected by mood or feelings of participants. For Kriengkrai (2007), terms of address can be variously called 'vocative', 'address terms', 'address forms', 'forms of address' and 'theory of address'. According to Braun's (1988) classification, terms of address can be divided into three main categories or three word classes as follows: 'pronoun', 'verb' and 'noun'.

However, names as forms of address terms show the relationship between language and the society (Salihu, 2014). Names play important roles in the society because they symbolise a man's social position in relation to the people around him and his status is readily recognised. Thus, terms of address used to express intimacy can be called terms of endearment, pet names, sweet words, affectionate talk or terms of affection. Agnieszka (2015) posits that "terms of endearment serve to convey two main functions; on one hand, in some areas, they are part and parcel of everyday speech and one may find it unusual if they are left out because they express emotions and strengthen ties; on the other hand, such words may be perceived as disparaging or condescending, as they may imply incompetence, foolishness or weakness of addressee". Thus, it is a form of address; a word or phrase employed either to address or describe a person, animal, or inanimate object for which the speaker feels affection. Laudau (2015) observes that the use of pet names is a good thing in relationships because partners who have developed pet names for their romantic partners use these names in expressing their affection for each other and also as an inside language when they are alone. Agnieszka (2015) subdivides terms of endearment into smaller sets. The vast majority of the sweet words fit into the mechanism of animal metaphor called 'zoosemy'. They include chick, chuck, bunny, turtle, dove, lamb, duckling, lambie, kitten, mouse etc. Others belong to 'foodsemy'- honey, cupcake, honey pie, sugar, muffin, cookie, peach, sugar pie etc.; 'Plantosemy'buttercup, pumpkin etc.; 'toy endearment terms'- doll, baby doll etc.; 'royal terms' - queen, princess, duchess, king etc.; 'sky terms'- star, sunshine, sun etc. Rakhman and Setiawan (2014) further note that terms of address are considered to 
be polite and familiar terms used to show great intimacy. They maintain that address terms can be first name, nicknames, last name, title, multiple names, kinship terms, endearment terms and zero terms.

Afful and Nartey (2013) observe that terms of endearment can further be derived from coinages relating to personal names of the addressees. They observe that such forms are coined either from deletion of a vowel or consonant sound (hypocoristic forms) or insertion of a vowel or consonant sound. They further note that there are instances of reduplication. Examples are Lam-Lam (derived from Lamar), Georgie-Porgie (derived from George), Markiiiii (derived from Mark), Queeny (derived from Queen) and Narty (derived from Nartey). Afful and Nartey (2013) note that despite the fact that their research uses English as a major means of communication, most of the terms of endearment identified were rendered in other languages; thereby pointing the use of terms of endearment for socio-pragmatic purposes and multi-lingual situation of the University studied.

Umeodinka (2015) studies affective meaning as it relates to marital life in Igbo. The research work seeks to examine what affective meaning is, kinds of expressions that indicate positive and negative affective meaning, ordinary meaning of these expressions and the effects of their usage in the marital life of the Igbo. Umeodinka (2015) uses data elicited from twenty couples chosen using the purposive sampling technique. He observes from his findings that affective expressions can be either positive or negative. Again, he observes that the old generation wives emphasise strong and responsible husbands as against the young generation, whose aim is mainly on love and mode of wealth of their husbands. Also, between the educated and non-educated couples, he finds out that the educated use a mixture of English and Igbo expressions while the non-educated use Igbo expressions. For the urban versus the rural dwelling couples, Umeodinka (2015) notes that the urban dwelling wives reflect socialisation and sophistication as they use more of English emotional expressions than the rural dwelling wives who use less English expressions. From the study, he concludes that emotional expressions are used based on the expression of personal love and beauty, indication of personal mood, appreciation and pride, walking into husband's psychology, promotion of youthfulness in marriage, maintenance of marriage fun and sexual pleasure, expression of annoyance etc.

\section{Methodology}

This research adopts the survey design. This is to enable the researchers assess a wide variety of behaviours and other phenomena that can be studied in a typical naturalistic observation study. The area for obtaining data for this research work is Nsukka metropolis, Enugu State, Nigeria. This work focuses on couples (married men and women) within Nsukka metropolis; the educated and the non-educated. The choice of this population is to get first hand information on what pet names are used by these couples and what these names mean to these couples. This study adopts a random purposive sampling technique. This implies that from each of the regions, 15 couples are selected randomly to meet the need of obtaining necessary data for the study. Oral interview is employed in getting the required data for the research. Information gathered from the interview is analysed using descriptive method. This method is chosen because it is needful to explain and describe the pet names used by these couples.

\section{DATA PRESENTATION AND ANALYSIS}

\section{A. Presentation of Data}

TABLE I

SHOWING PET NAMES IDENTIFIED IN THE STUDY AREAS

\begin{tabular}{|c|c|c|c|}
\hline COMMUNITIES & $\begin{array}{l}\text { PET NAMES FOR MALE } \\
\text { SPOUSES }\end{array}$ & $\begin{array}{l}\text { PET NAMES FOR FEMALE } \\
\text { SPOUSES }\end{array}$ & $\begin{array}{l}\text { PET NAMES FOR NEUTER } \\
\text { GENDER }\end{array}$ \\
\hline NGWURU & $\begin{array}{l}\text { Daddy, Pàpáā } \bar{m} \text {, Pàpá, Ńnà ḿ } \\
\text { úkwú }\end{array}$ & $\begin{array}{l}\text { Mummy, Ńnē, Òriàkù ḿlÒrièkụ ḿ, } \\
\text { Bèkéè ṁ, Missis }\end{array}$ & Ǹkè ḿ, Darling \\
\hline ECHARA & Daddy, Pàpáā $\bar{m}$, Ńnà ḿ úkwú & $\begin{array}{l}\text { Sòsòrísò, Lọọ̀lọ mín Ńnē, Mummy, } \\
\text { Nwáènyì ómálNwáànyì ómá, } \\
\text { Òríekụ, Missis, Ómárịchá } \bar{m}\end{array}$ & Dear, Ǹkè ḿ, Òyòó ḿ, Bestie, Mine \\
\hline AMAEZE & Daddy & $\begin{array}{l}\text { Bèkéè ḿ, Ńnē, Mummy, Lóòlò mi, } \\
\text { Òrièkù ḿ, Ómárị́chá } \bar{m},\end{array}$ & $\begin{array}{l}\text { Oyyò ḿ, Ónyée } \bar{m} / \text { Ónyé ǹkè m, Nंkè } \\
m, \text { Òdị̂nnóbì, My darling, Dear }\end{array}$ \\
\hline NRU & Pàpáā $\bar{m}$, Daddy, Ńnà ḿ úkwú & $\begin{array}{l}\text { Oriékù ḿ, Mummy, Lọọlò ḿ, My } \\
\text { queen }\end{array}$ & $\begin{array}{l}\text { Dear, Sweetheart, Ưtọ́ } \bar{m}, \text { Nkè } \dot{m} \text {, } \\
\text { Òyóó } m \text {, Bestie }\end{array}$ \\
\hline IHE N'OWERRE & $\begin{array}{l}\text { Hubby, King (B,I), Daddy, Ńnà } \\
\text { '́ úkwú }\end{array}$ & $\begin{array}{l}\text { Nwáènyì ómá, Mummy, Lọòlọ mi, } \\
\text { My queen }\end{array}$ & $\begin{array}{l}\text { My world, òdịmnóbi, Ǹkè } m \text {, } \\
\text { Ónyée } \bar{m} \text {, Dear, Ȯyòó ḿ, My love }\end{array}$ \\
\hline $\begin{array}{l}\text { UNIVERSITY } \\
\text { COMMUNITY }\end{array}$ & Daddy, My cute, Hubby, & $\begin{array}{l}\text { Mummy, Ńnē, My angel, Bèkéè } \bar{m} \text {, } \\
\text { My queen, Ómárịchá } \bar{m}\end{array}$ & $\begin{array}{l}\text { Honey, Mine, ㅊkè m, My love, } \\
\text { Best m, Dear, Darling, Sweetheart, } \\
\text { Òyóó } m\end{array}$ \\
\hline
\end{tabular}

The table above shows pet names used among couples in Nsukka metropolis according to the six regions under study. These regions include Ngwuru, Echara, Nru, Amaeze, Ihe n'Owerre and the University community. The pet names sourced are subdivided into; pet names used for male spouses, pet names used for female spouses and pet names for neuter gender (both male and female spouses). It is pertinent to know that most of these pet names occurred almost in

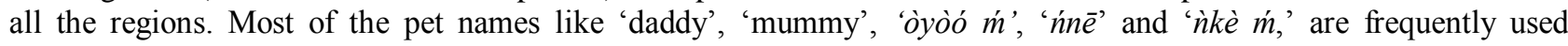


notwithstanding how long the couples have been married. However, the most frequently used pet names are 'nikè 'm', 'daddy', 'òrièkụ', 'dear', and 'mummy'.

\section{B. Implications of Pet Names Used among Couples in Nsukka Metropolis}

From the data presented in Table I, pet names used among couples in Nsukka metropolis are shown. From the research carried out, it is observed that most of the pet names have reasons why they are used. Names like ńnē, mummy, òrièkù $\dot{m}$, my queen, my angel portray the femininity of a female spouse; others like ómárịchá $\bar{m}$, bèkéè ḿ and my angel, are used by male spouses to express how beautiful their female spouses are; others like òyó $m$, my love, best, bestie, ónyée m/ónyé ǹkè ḿ and òdịmnóbì are used to express friendship and closeness of the spouses to one another. Furthermore, female spouses use names like daddy, pàpáā $\bar{m}$ /, pàpá, ńnà ḿ úkwú, hubby, King (B, I); first letter of spouse's name, to express their respect for their male spouses while names like 'my cute' are used by female spouses to

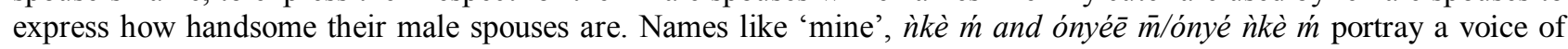
possession to show that the spouse belongs exclusively to the other spouse. The pet names 'sòsorisò', 'honey', 'sweetheart', 'ìtó $\bar{m}$ ' are used by the couples to express how they feel about the sweet nature of one another.

There are also implications associated with negative names used among couples in Nsukka metropolis. According to these couples, they use such address term either when they are angry about each other's disposition or when they are not in good terms with each other. Some also use tekonyms; names that refer to a spouse as the father or the mother of soand-so (their child's name) like pàpá/màmá Ikechukwu, Aboyi, Udochukwu etc. when they start having children. One of the women interviewed said she uses such term of address on her husband when she notices that her husband no longer cares about her as he does when they were newly married. The use of a spouse's first name also occurred from the study conducted. The use of first names like Ikechukwu, Emeka, Elizabeth, and Maria often arise when a spouse is not happy with the other spouse or when they are angry. Another reason for the use of a spouse's first name according to a woman interviewed is to show cordiality when they are alone with each other.

\section{Sociolinguistic Factors That Affect the Use of Pet Names among Couples in Nsukka Metropolis}

There are factors that lead to differences in the use of pet names among couples in Nsukka metropolis. These factors include: age (number of years the couples have been married), gender (male or female spouse), educational background (educated and non-educated couples), occupation, region (rural and urban areas) and contact.

\section{Age (Number of years the couples have been married)}

From the study conducted, it is observed that younger couples who have been married for 1-15 years use pet names that mostly express their feelings for their spouses. They also adopt pet names that speak more about their partners' looks and how beautiful or handsome they are. These names include: my love, sweetheart, darling, best, bestie, ómárị́chá $\bar{m}$, békéè ḿ, my cute, my angel etc. Most couples in this category find it difficult to address their partners with either their first names or their children's names. This is because for them, the marriage is still new and they believe the contemporary age is a modern age where everyone will like to be seen as someone who is sophisticated.

However, couples who have been married for 16 years and above mostly use pet names that convey their respect and honour to their spouses. This is because during their time of marriage, the world has not been modernised as it is now. It is worthy to note this does not imply that couples married for 1-15 years do not show respect to one another. Couples within this category prefer to use pet names such as daddy, mummy, ńnà ḿ úkwú, ńnē, ǹkè ḿ, pàpáā $\bar{m} /$ pàpá, nwáènyì ómá, missis etc. Furthermore, these groups of couples mostly address their partners with their children's names. This comes naturally among most of the couples as they tend to move from pet names to using tekonyms as terms for addressing their partners as soon as they start having children.

\section{Gender (Male or female spouses)}

Male and female spouses use pet names differently. Male spouses usually use pet names that express the femininity of their partners. These names portray the female partners as beautiful; ómárịchá $\bar{m}$, my queen, bèkéè ḿ, my angel; and feminine; ńnē, mummy, òrièkù mí, lóòlọ ḿ, nwáènyi ọmá. On the other hand, female spouses use pet names that portray their partners as being masculine; daddy, pàpáa $\bar{m} /$ pàpá, hubby, ńnà ḿ úkwú, king (B, I); handsome; 'my cute'.

It is worthy to note that from the study carried out, both male and female spouses use other terms in addressing their partners. However, the female spouses prefer to use their partners' first names or tekonyms in addressing their partners instead of using terms like 'nwókē $\bar{a}$ ' (this man), 'ògá' (my lord) etc but the male partners use more often, terms like 'nwáènyị a' or 'nwáènyị hụ' (this or that woman) in addressing their female partners. They also address their partners using their children's names (tekonyms).

\section{Educational background (Educated and non-educated couples)}

The level of education of couples also serves as a determinant to their use of pet names. Education brings one in contact with Western culture and civilisation, thus, educated couples tend to use pet names that are in tandem with their educational status. They mostly use pet names that portray them as being sophisticated and learned. Educated couples both within the university community and outside use English pet names mostly. This is because English is Nigeria's official language and a universal medium of communication; Nigeria being a multilingual nation. Therefore, educated couples make use of pet names like mummy, mine, daddy, darling, my world, my love, sweetheart, dear, honey, hubby, my cute, king (B, I). Most educated couples who have been married for 1-10 years use these names because they see themselves as sophisticated people. 
On the other hand, most non-educated couples who have less or no contact with Western education often use pet names that are available in their dialect/language. Since these couples have no integrity to save, they make do with what is obtainable within their locality. These groups of couples use pet names like ńne, nwáènyị ómá, óríèù mí ụtọ́ $\bar{m}$,

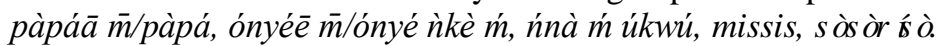

\section{Occupation}

Different works people do also affect their use of pet names towards their partners. It is gathered from the study conducted that most business men and women use pet names like ìkè ḿ, òyòó $m$, daddy, mummy, dear, òríăkù, pàpáa $\bar{m}$. Also, petty traders and way side traders use pet names like sòsòrísò, ńnè, ńnà ḿ úkwú, missis, òríekù. Couples who are civil servants, nurses, chemists and teachers often use pet names like daddy, mummy, dear, mine, best, bestie, honey, darling, sweetheart. However, the name 'nkè 'm' is generally used notwithstanding the couples' occupations or societal classes.

\section{Region}

Another sociolinguistic factor that affects the use of pet names among couples in Nsukka metropolis is the region in which the people live. This could be a rural or urban area. For this study, areas under study like Echara, Ihe n'Owere, $\mathrm{Nru}, \mathrm{Ngwuru}$, and Amaeze are all rural areas. It is observed that pet names used in these areas are mostly Igbo pet names except for people who have had contact with other areas. Thus, prevalent pet names used in these areas include:

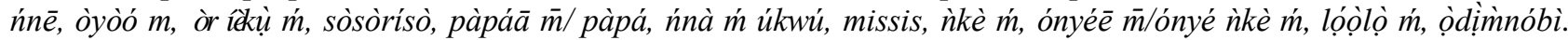
They also use English pet names like daddy, mummy, dear, darling, mummy, hubby, king (B, I) but these names are not often used. Most of the couples in these rural areas use other terms of address like nwáènyị / nwáènyị hụ́, calling their partners by their children's names or using their partners' first names.

In the University of Nigeria community, which is considered to be an urban area, it is observed that couples there use mostly English pet names; however, few of them use Igbo pet names. They use pet names like mummy, mine, daddy, my angel, my cute, my love, best, bestie, my queen, dear, darling, sweetheart, honey, and hubby. Some Igbo pet names

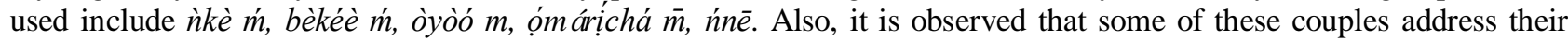
partners using other address terms like calling them their children's names (tekonyms).

\section{Language of Communicating Pet Names among Couples in Nsukka Metropolis}

Couples in Nsukka metropolis use both English and Igbo pet names in addressing themselves. Most of these couples use both Igbo and English pet names in addressing their respective partners. It is rare to see a couple who uses Igbo or English pet names exclusively. Furthermore, the use of these pet names differs due to some sociolinguistic factors like age, gender, occupation, region and educational background.

Older couples who have been married for 25 years and above use Igbo pet names majorly, though they also use English pet names that can be said to be general among couples like daddy, mummy, dear and sweetheart; while younger couples married for 1-20 years mostly use English pet names though some of them also make use of Igbo pet names. Couples married for 20-25 years are observed to use both English and Igbo pet names so far as they are able to communicate their feelings about their spouses. On the basis of occupational influence, couples that are civil servants mostly use English pet names while couples who are either business men or farmers mostly use Igbo pet names though there are traces of English pet names among these groups. Couples living in the rural areas tend to use more of Igbo pet names than those who reside in urban areas, who have had contact with both education and civilisation. Also, couples that are educated mostly address their partners using English pet names though some of them also prefer to use Igbo pet names that better convey their feelings for their partners. However, non-educated couples, though they make use of English pet names, employ Igbo pet names more due to their environment and occupation which is mostly business and farming.

Non-educated couples who reside in the rural areas, whose occupation is either business or farming, frequently employ Igbo pet names in addressing their spouses. These couples may fall under any of the duration used above; they might be newly married couple, middle aged couple or older couple, while educated couples who reside in urban areas, who are mostly civil servants, frequently use English pet names.

\section{SUMMARY AND CONCLUSION}

This study is carried out in six regions of Nsukka Local Government Area of Enugu state, Nigeria; Ngwuru, Echara, $\mathrm{Nru}$, Ihe n'Owerre, Amaeze and the University community. From the findings, it is observed that couples within these regions use (thirty-one) 31 pet names which co-occur among couples in these regions. From the study, couples who have lived for 1-15 years mostly employ English pet names due to their exposure to education and civilisation which couples that have lived together for 20 years and above might not have. Furthermore, in terms of regions (where these couples dwell), it is observed that couples living in rural areas like Ngwuru, Nru, Echara, Amaeze and Ihe n'Owerre use Igbo pet names more than those who live in Nsukka urban area like the University community. Unlike the non-educated couples, the educated couples employ pet names that showcase their integrity as educated people. They mostly employ English pet names. It is also pertinent to note that educated couples do not usually address their spouses using their children's names because they see it as archaic or out of fashion for educated or civilised people. Thus, factors like age, gender, educational background and region have been identified as sociolinguistic factors that determine which of the 
pet names is used by each couple and how often they use these pet names in expressing their feelings towards their partners.

Furthermore, it could also be deduced that the languages of communicating these pet names among couples within Nsukka metropolis are the English and Igbo languages. The use of either of these languages is also determined by sociolinguistic factors like age (number of years the couples have lived together), gender, educational background and region. Couples who reside in rural areas employ Igbo pet names more those who reside in urban areas. This is because couples in urban areas have opportunities to formal education and civilisation than those dwelling in the rural areas. It is also important to note that couples also use a particular language; the Igbo or English language depending on the feelings they want to communicate to their spouses. They use the language that enables them express their feelings better to their spouses. Some educated couples who use Igbo pet names do so not because there are no available pet names in the English language rather, they want to use a suitable language to communicate their feelings. However, the language for communicating pet names among couples in Nsukka metropolis depends on what the couples want to achieve with the pet names they employ.

\section{APPENDIX}

Table showing meaning of Igbo pet names used among couples in Nsukka metropolis

\begin{tabular}{|c|c|}
\hline IGBO PET NAMES & GLOSS/MEANING \\
\hline Pàpáā $\bar{m}$ & My father \\
\hline Pàpá & Father \\
\hline Ńnà ḿ úkwú & My lord \\
\hline Ńnē & Mother/Dear \\
\hline Òríàkụ ḿ/ Òríèkụ̀ ḿ & The one that consumes my wealth \\
\hline Bèkéè ḿ & My English baby \\
\hline Ǹkè ḿ & Mine \\
\hline Sòsòrísò & Sexy queen \\
\hline Lọoọ̀lọ̀ ḿ & My queen \\
\hline Nwáànyị ọ́má/ Nwáènyị ọ́má & Good woman/ Beautiful woman \\
\hline Òyòó ḿ & My friend \\
\hline Ọmárịchá $\overline{\mathrm{m}}$ & My finest \\
\hline Ónyéē $\overline{\mathrm{m}}$ & My person \\
\hline Ónyé ǹkè ḿ & My personal person \\
\hline Òdị̂mnóbì & The one in my heart \\
\hline
\end{tabular}

\section{REFERENCES}

[1] Afful, J. B. \& Nartey, M. (2013). 'Hello sweetie pie' - A sociolinguistic analysis of terms of endearment in a Ghanaian University. The International Journal of Social Sciences, 17(1), 92-101.

[2] Agnieszka, G. (2015). On the semantic history of selected terms of endearment. Linguistics Beyond and Within, 1, $104-118$.

[3] Bing, J. (1993). Names and honorific pronouns in Gborbo Khran. In S.S. Mufewere \& L.P. Moshi (Eds.), Topics in African linguistics (pp. 119-130). Amsterdam and Philadelphia: John Benjamins Publishing Co.

[4] Braun, F. (1988). Terms of address: Problems of patterns and usage in various languages and cultures. Berlin: Mouton de Gruyter.

[5] Holmes, J. (1992). An introduction to sociolinguistics. London: Longman.

[6] Hudson, R.A. (1996). Sociolinguistics (2nd ed.). Cambridge: Cambridge University Press.

[7] Kriengkrai, W. (2007). Socio-cultural reflections on the address terms in the lyrics of Thai country and city songs. Journal of the Siam Society, 95, 143-158.

[8] Laudau, E. (2015). Terms of endearment: Why use pet names in relationships. Retrieved from http://blogs.scientific.com/mind.../why-do-we-use-pet-names-in-relationships.... Accessed 11th April, 2018.

[9] Mahzad, M. (2012). The role of age and gender in the choice of address forms: A sociolinguistics study. International Journal of Applied Linguistics and English Literature, 1(4), 173-182.

[10] Mallinson, C. (2015). Sociolinguistics. Baltimore: Oxford University.

[11] Olieh, P.C. (2001). The contextual meaning of names in Igbo land. B.A project, Department of Linguistics, Igbo and Other Nigerian Languages, University of Nigeria, Nsukka.

[12] Rakhman, A. \& Setiawan, S. (2014). Terms of address used by students of English courses in Kampong Inggris Pare-Kediri. Universitas Negeri Surabaya: E- Journal, 1(1), 1-6.

[13] Salihu, H.H. (2014). The sociolinguistic study of gender address patterns in the Hausa society. International Journal of Social Science and Humanities, 4(1), 48-53.

[14] Umeodinka, A.U. (2015). Affective meaning: The case of marital life in Igbo. Ph.D seminar, Department of Linguistics, Igbo and Other Nigerian Languages, University of Nigeria, Nsukka.

[15] Yule, G. (2006). The study of language. Cambridge: Cambridge University Press. 
Chinedu Chidiebere Ezebube was born at Fegge Onitsha, Anambra State, Nigeria. He obtained his first degree in Linguistics and Igbo studies from the University of Nigeria, Nsukka. From the same institution, he got his Masters Degree, majoring in Igbo Literature and Stylistics. Presently, he is a lecturer at the Department of Linguistics, Igbo \& Other Nigerian Languages, University of Nigeria. His research interest includes African/Igbo literature, gender and cultural studies, and sociolinguistics.

Ogechukwu Uchenna Chukwuneke was born at Onitsha, Anambra State, Nigeria. She obtained her first degree in Igbo Studies from Nnamdi Azikiwe University, Awka, Anambra State. She also obtained her Master's Degree from the same institution, majoring in Igbo Literature and Stylistics. She is currently a lecturer at the Department of Linguistics, Igbo \& Other Nigerian Languages, University of Nigeria. Her research interests include African/Igbo Literature, Literary criticism and Sociolinguistics.

Ekpereamaka Jennifer Onuagha was born at Ichi, Anambra State, Nigeria. She is a graduate student at the Department of Linguistics, Igbo \& Other Nigerian Languages, University of Nigeria. She is interested in the core areas of Linguistics via Phonetics and Phonology. 